Research Article

\title{
Assessment of knowledge regarding prevention and treatment of Ebola virus among undergraduate medical students in Chennai, India: a questionnaire based study
}

\author{
A. Umamageswari ${ }^{1 *}$, Balaji Arumugam ${ }^{2}$, R. Nandini ${ }^{1}$, I. Nasrunisha ${ }^{3}$
}

\begin{abstract}
${ }^{1}$ Department of Pharmacology, Tagore Medical College and Hospital, Chennai, Tamil Nadu, India, ${ }^{2}$ Department of Community Medicine, Tagore Medical College and Hospital, Chennai, Tamil Nadu, India, ${ }^{3}$ Tagore Medical College and Hospital, Chennai, Tamil Nadu, India
\end{abstract}

Received: 20 September 2015 Accepted: 28 September 2015

\section{*Correspondence to: \\ Dr. A. Umamageswari, Email: leeuma6@gmail.com}

Copyright: (C) the author(s), publisher and licensee Medip Academy. This is an openaccess article distributed under the terms of the Creative Commons Attribution NonCommercial License, which permits unrestricted noncommercial use, distribution, and reproduction in any medium, provided the original work is properly cited.

\begin{abstract}
Background: Ebola virus disease is a dreadful condition associated with high mortality rate threatening the entire world. Our study was aimed to assess the knowledge and to create awareness about Ebola among undergraduate medical students.

Methods: A self-administered, pretested questionnaire with 30 questions focusing on the general information of virus, mode of transmission, clinical features and complications of the infection, diagnosis, treatment, preventive measures, and epidemiological features was given to the study participants. Scoring system was followed, and statistical analysis was done using Chi-square test and comparison between different sections by one-way analysis of variance.

Results: Totally, 263 medical students participated in the study. Based on the percentile of scores obtained they were categorized into three groups, better knowledge (18-30), average knowledge (10-17), poor knowledge (0-9). On the whole 70\% students had an average level of knowledge $25 \%$ students had better knowledge and $5 \%$ students had poor knowledge. Female students had better knowledge when compared to male students $(\mathrm{p}<0.0001)$. Similarly, second year students had better knowledge than interns and final year students $(\mathrm{p}<0.0001)$. Students had less knowledge regarding clinical features, epidemiological features and relatively poor knowledge regarding diagnosis and treatment. Comparatively, knowledge about mode of transmission, preventive measures and general information of virus were better.

Conclusion: This study demonstrates apparent lack of knowledge regarding various aspects of Ebola and emphasis to conduct awareness programs to manage the dreadful consequences of the disease if rises.
\end{abstract}

Keywords: Ebola virus, Knowledge, Questionnaire, Scores, Medical students

\section{INTRODUCTION}

Ebola virus disease (EVD), which was formerly known as Ebola hemorrhagic fever, is an acute, communicable and serious illness with high mortality rate. Ebola is a single-strand, negative-sense RNA virus belongs to the Filoviridae family. ${ }^{1,2}$ There are five species of Ebola virus named after the areas where they originated. Four of which known to cause disease in human - Zaire, Sudan, Tai forest, and Bundibugyo. The fifth, Reston Ebola species affects non-human primates. ${ }^{3}$ Ebola was first discovered in 1976 near the Ebola river is now the democratic Republic of the Congo. Since then, outbreaks have appeared sporadically in many countries of Africa. ${ }^{4}$ The current 2014 Ebola outbreak in West Africa has been declared as "Emergency of International Concern" by the World Health Organization (WHO). As on September 2015, total of 28,183 confirmed cases and 11,306 deaths have been reported. ${ }^{5}$ Of which, majority of cases are from Guinea, Liberia, Sierra Leone and few from Italy, Spain, the United Kingdom, the United states of America, Nigeria, Senegal, and Mali. Until date, no case has been reported from India.

Scientists believe that fruit bats may be the natural host of the Ebola virus in Africa, responsible for transmitting the virus to other animals such as apes and monkeys. In humans, the 
virus is transmitted through direct contact with blood and body fluids of the infected individuals via broken skin or mucous membrane. It can also be transmitted through the use of contaminated syringe needles, bed sheets, pillows, stethoscopes with body secretions of the infected patients. ${ }^{6}$ However transmission does not occur through air, water, food, or mosquitoes. Though there are no studies on the survival of Ebola outside the body fluids, experts suggest EBV may die within 24 hrs. EBV can cause infection only if it stays in wet body fluids. Symptoms of Ebola disease usually appear 2-21 days of its infection. Initial symptoms of Ebola are sudden onset of fever, intense muscle weakness, and headache, sore throat followed by vomiting, diarrhea, rash, impaired hepatic and renal functions. In some cases, it leads to internal and external bleeding. ${ }^{7}$ Death if occurs, is typically 6-16 days after symptoms start. No blood test is available to detect the EBV before a person has symptoms. Confirmatory specialized laboratory tests such as enzyme linkedimmunosorbent assay, reverse-transcriptase polymerase chain reaction assay, and electron microscopy are available to detect the patients with typical symptoms. Recovery from Ebola depends on access to health care, good clinical care, and person's immune status. In men who recovered from Ebola, the virus can persist in semen for a period of 70-90 days. The Ebola virus has been detected in breast milk and urine also. As of now, no specific medicine or vaccine has been proven to cure Ebola. Only symptomatic treatment is given to increase the chance of survival which includes providing fluids and electrolytes, maintaining oxygen status, blood pressure and treating infections if any. ${ }^{8}$ Healthcare workers, relatives and friends of Ebola patients are at greatest risk of getting sick through contact while caring for the ill and through funeral practices. Strict and effective infection control measures such as wearing gloves, gown, facemask should be followed while handling the Ebola patients.

According to WHO global update, Ebola in West Africa is an "Extraordinary Event" where coordinated international response is expected to stop further spread of infection. Earlier few studies were conducted to assess the knowledge regarding Ebola virus among junior resident doctors, ${ }^{9}$ pharmacist, ${ }^{10}$ health care personnel, ${ }^{11}$ and general population. ${ }^{12}$ After an extensive search, we would not find studies involving medical students. This prompted us to take up the study which was aimed to assess the knowledge and to create awareness about Ebola among undergraduate medical students who are the budding doctors of today will be the pillars of healthcare system of tomorrow.

\section{METHODS}

A cross-sectional survey was conducted in Tagore Medical College and Hospital, Chennai, Tamil Nadu, India by the department of Pharmacology, to assess the knowledge about Ebola among undergraduate medical students a selfadministered, pretested questionnaire was given to them. Institutional Ethical committee approval was obtained before start of the study. After explaining the objectives of the study and taking oral informed consent, questionnaires were distributed to the participants. The content of the questionnaire was validated by a team of professionals from various Departments such as Pharmacology, Microbiology, Community Medicine, Pathology, and Medicine. After thorough literature search the questionnaire was formulated as close ended questions with 30 questions, which was divided into six sections. Out of 30 questions, section one has 4 questions which focused on the general information of the virus, section two has 8 questions dealing with mode of transmission, section three has 4 questions which focused on clinical features and complications of the infection, section four has 6 questions dealing with diagnosis and treatment, section six has 3 questions which focused on preventive measures and epidemiological features. Each question has 3 options, one right answer and 2 wrong answers. Each right answer was given a score of " 1 " and wrong answer "0." Multiple answers for a given question and questions not answered were considered as invalid. Scoring system was followed for evaluating the questionnaire based on the percentile of scores obtained by the study participants. They were categorized into three groups, better knowledge (18-30), average knowledge (10-17), poor knowledge (0-9). Demographic data such as gender, year the student belong were included. The questionnaire was completed by a total of 263 undergraduate medical students and interns of Tagore Medical College and Hospital. All the data were tabulated and analyzed using appropriate statistical methods.

\section{RESULTS}

A total of 263 medical students participated in the study, 51 were interns, 86 were in final year, 126 were in second year. Among interns 35 were females and 16 were males, in final year students 56 were females and 30 were males, in second year 64 were females and 62 were males. On the whole, female students (155) were more when compared to male students (108).

When assessing the overall knowledge about the disease with respect to gender, $183(70 \%)$ students have average level of knowledge of which 93 were females and 90 were males, only $67(25 \%)$ students have better knowledge of which majority 62 were females and 5 were males and $13(5 \%)$ students have poor knowledge notably all are males as shown in Figures 1 and 2.

While assessing the overall knowledge with respect to student's year, interns fall under average and poor knowledge category when compared to second year students were in better and average categories. All the final year students come under average knowledge category as shown in Figure 3.

Table 1 shows the total score obtained by the students. Out of 30 questions, 24 was the maximum score and 6 was the minimum score, whereas overall mean score obtained was 15. 12 with the standard deviation of 3.419 . According to 


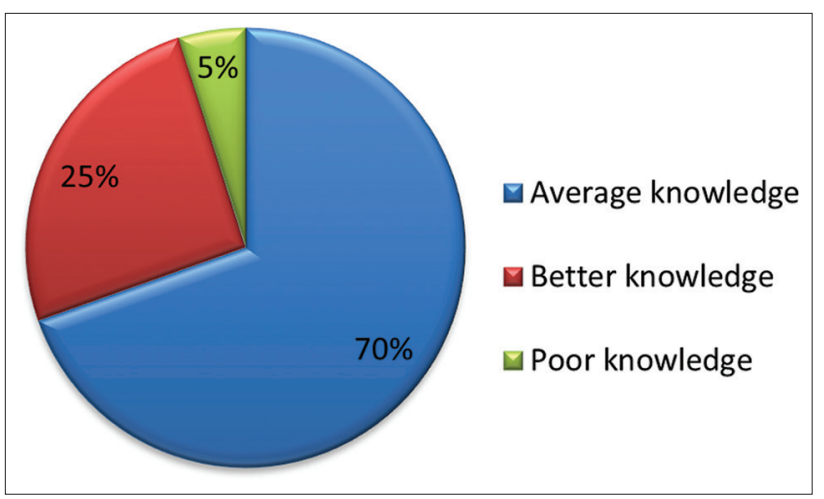

Figure 1: Percentage level of knowledge among medical students.

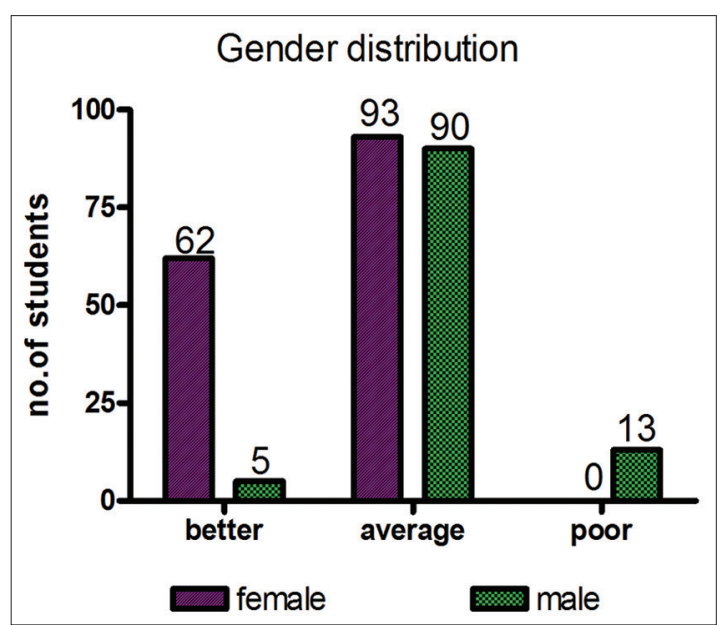

Figure 2: Level of knowledge versus gender.

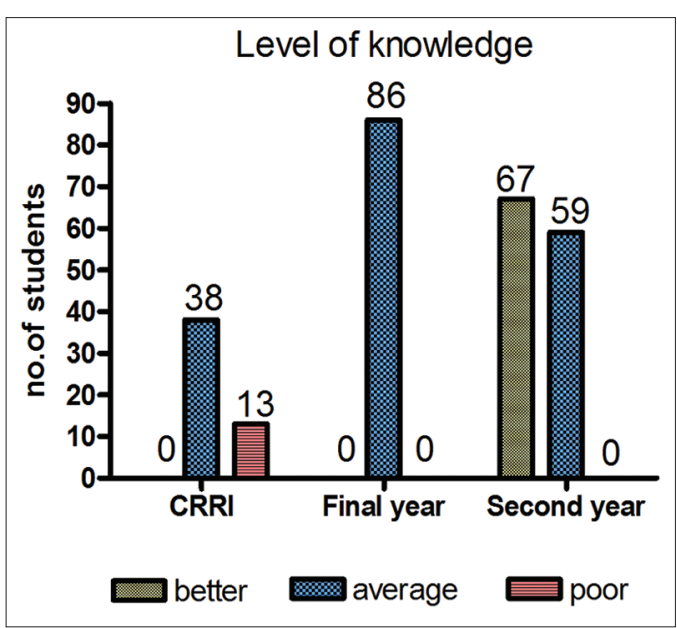

Figure 3: Level of knowledge versus year.

Table 2 which depicts number of students obtained the particular score, most of the students had scores ranging from 10 to 19 . Only 2 students had secured the highest score of 24 , whereas only one student has secured the lowest score of 6 .

Table 3 depicts the scores analyzed according the different sections of the questionnaire and expressed in mean and standard deviation. The means scores in the sections 1, 2, and 5 were statistically significant and the respective $p$ values
Table 1: Evaluation of total score secured by the students $(n=263)$.

\begin{tabular}{|lc|}
\hline Total number of questions & 30 \\
\hline Mean & 15.12 \\
\hline Median & 15.0 \\
\hline Standard deviation & 3.419 \\
\hline Range & 18 \\
\hline Minimum & 6 \\
\hline Maximum & 24 \\
\hline
\end{tabular}

Table 2: Frequency of students secured the scores.

\begin{tabular}{|lc|}
\hline Scores & Frequency of students \\
\hline 6 & 1 \\
\hline 7 & 3 \\
\hline 8 & 4 \\
\hline 9 & 5 \\
\hline 10 & 12 \\
\hline 11 & 13 \\
\hline 12 & 20 \\
\hline 13 & 23 \\
\hline 14 & 34 \\
\hline 15 & 26 \\
\hline 16 & 32 \\
\hline 17 & 23 \\
\hline 18 & 24 \\
\hline 19 & 20 \\
\hline 20 & 6 \\
\hline 21 & 8 \\
\hline 22 & 7 \\
\hline 24 & 2 \\
\hline
\end{tabular}

were given. Furthermore, Table 3 shows the maximum and minimum scores secured by the students under each section. While analyzing the data using one-way analysis of variance, students had less knowledge with respect to clinical features, epidemiological features of the disease and relatively poor knowledge regarding diagnosis and treatment. Comparatively, knowledge regarding mode of transmission, preventive measures and general information of virus were better.

The analysis of data using Chi-square test implies, females were having more knowledge than males which was statistically highly significant with the $p<0.0001$. Similarly when the different academic years were compared like second year, final year and Interns, the second year students had more knowledge than other two groups and which was statistically significant with the $\mathrm{p}<0.0001$.

\section{DISCUSSION}

Ebola virus which is native to Africa is spreading fast across many countries and has become a threat for rest of the 
Table 3: Evaluation of scores for each section secured by the students.

\begin{tabular}{|lcccccc|}
\hline Parameters & \multicolumn{5}{c|}{ Number of questions } \\
& $\mathbf{4}$ & $\mathbf{8}$ & $\mathbf{4}$ & $\mathbf{6}$ & $\mathbf{5}$ & $\mathbf{3}$ \\
& Section 1 & Section 2 & Section 3 & Section 4 & Section 5 & Section $\mathbf{6}$ \\
\hline Mean \pm SD & $2.25 \pm 1.07$ & $2.56 \pm 1.33$ & $2.93 \pm 0.97$ & $2.76 \pm 1.23$ & $3.36 \pm 1.27$ & $1.26 \pm 0.83$ \\
\hline Median & 2.00 & 2.00 & 3.00 & 3.00 & 3.00 & 1.00 \\
\hline Minimum score & 0 & 0 & 0 & 0 & 0 & 0 \\
\hline Maximum score & 4 & 7 & 4 & 5 & 5 & $0.041 *$ \\
\hline p value & $0.000 *$ & $0.009 *$ & 0.117 & 0.402 & 0.135 \\
\hline
\end{tabular}

${ }^{*} \mathrm{p}<0.05$, SD: Standard deviation, Section 1: General information about virus, Section 2: Mode of transmission, Section 3: Clinical features and complications of the infection, Section 4: Diagnosis and treatment, Section 5: Preventive measures, Section 6: Epidemiological features

world. To put an end to the current Ebola outbreak WHO has launched phase 3 framework which incorporates new knowledge and tools into the ongoing Ebola response and recovery work. This framework aims to keep a check on the emergence of new cases and thereby limiting the onward transmission of disease. ${ }^{13}$

In our study, the findings revealed that majority of the students $(70 \%)$ have average level of knowledge about the disease followed by $25 \%$ have better knowledge and remaining $5 \%$ have poor knowledge. Similar finding was observed in another study ${ }^{14}$ involving 50 general population of Ethiopia, 38 (76\%) have medium level of awareness on Ebola, 11 (22\%) have good awareness and $1(2 \%)$ have poor awareness. According to the study involving Nigerians ${ }^{15}$ by Shittu et al., 39\% had poor knowledge regarding Ebola whereas $25.5 \%$ had fair knowledge and $35.5 \%$ show good knowledge.

In our present study, the level of knowledge among female students is more when compared to male students. Our result is statistically significant and there is strong association between the knowledge about Ebola and gender variable. Naveed et al. in his study also stated that females were found to have more knowledge about Ebola disease compared to male group of different age and profession. Paucity of literature limits us from further comparing the gender variable with respect to knowledge of the disease.

On finding the association between knowledge and the year, surprisingly second year students outrages final year students and interns. Interns are at the frontline and would be the first to assess patients in the hospital. The apparent lack of knowledge about Ebola among interns could have deleterious consequences like missing out of Ebola infected patients at the early stage of the disease, need of personal protective equipment to limit the spread of imported Ebola virus if at all happens. Similar results was observed by Fazekas et al. involving junior doctors of various hospitals around England. His study concludes that junior doctors apparently show lack of knowledge about various aspects of Ebola. In another study involving community pharmacists, results indicate lack of knowledge regarding mode of transmission, vulnerable persons, treatment, and preventive measures.
Our study should be taken as an awakening call to initiate more extensive survey to assess awareness of EVD among clinicians of all grades, nurses and healthcare professionals. If these findings are confirmed by other similar studies, educational resources such as continued medical education, seminars, symposium, hands on training including proper usage of personal protective equipment, handling of infected patients may sensitize the relevant groups. These measures expected to achieve better awareness about Ebola among the medical fraternity and be well equipped to tackle this dreadful disease before the virus enters our country.

\section{CONCLUSION}

The present study highlights apparent lack of knowledge in all aspects of Ebola management. This is an optimal time to conduct awareness programs and hands on training to spread the knowledge about the disease.

\section{Funding: No funding sources}

Conflict of interest: None declared

Ethical approval: The study was approved by the Institutional Ethics Committee

\section{REFERENCES}

1. Feldmann H, Nichol ST, Klenk HD, Peters CJ, Sanchez A. Characterization of filoviruses based on differences in structure and antigenicity of the virion glycoprotein. Virology. 1994;199(2):469-73.

2. Sanchez A, Trappier SG, Mahy BW, Peters CJ, Nichol ST. The virion glycoproteins of Ebola viruses are encoded in two reading frames and are expressed through transcriptional editing. Proc Natl Acad Sci U S A. 1996;93(8):3602-7.

3. Top Questions on Ebola. Simple Answers Developed by the Association of State and Territorial Health Officials 2014. Available at http://www.astho.org/infectious-disease/topquestions-on-ebola-simple-answers-developed-by-astho/. Accessed 20 August 2015.

4. Douglas Country Health Department. Fact Sheet: questions and Answers on Ebola. Available at http://www. douglascountyhealth.com/latest-news/413-questions-and-y health department. Accessed 12 September 2015.

5. World Health Organisation. Fact Sheet: Ebola Situation 
Reports. Available at http://www.apps.who.int/ebola/ebolasituation-reports. Accessed 9 September 2015.

6. Martin-Moreno JM, Llinás G, Hernández JM. Is respiratory protection appropriate in the Ebola response? Lancet. 2014;384(9946):856.

7. McElroy AK, Erickson BR, Flietstra TD, Rollin PE, Nichol ST, Towner JS, et al. Ebola hemorrhagic fever: novel biomarker correlates of clinical outcome. J Infect Dis. 2014;210(4):558-66.

8. Naveed S, Sarwar G, Usmanghani K, Alam T, Sadia H, Alvi A, et al. Awareness of EVD (Ebola virus disease) in population of Karachi. J Pharm Pharm Sci. 2014;2(2)41-4.

9. Fazekas B, Fazekas J, Moledina M, Fazekas B, Karolyhazy K. Ebola virus disease: awareness among junior doctors in England. J Hosp Infect. 2015;90(3):260-2.

10. Elkerdasy A. Pharmacist's awareness about Ebola infections and their treatment in Riyadh, KSA. World J Pharm Sci. 2015;3(5):987-91.

11. Lakhani A, Mahmood H, Laeeq A, Mansoor S, Lodhi S, Majid S, et al. Viral hemorrhagic fever in Pakistan: awareness among health care personnel. J Pak Med Assoc. 2002;52(5):214-7.
12. Madhavi K, Berhe T. Awareness of Ebola virus disease among general population, Ethiopia. Int $\mathrm{J} A d v$ Res. 2015;3(6):713-20.

13. World Health Organisation. Fact Sheet: global Alert and Response. Available at http://www.who.int/ihr/global_alert/ en/. Accessed 14 September 2015.

14. Sailaja P, Madhavi K. Awareness of Ebola among general population, Ethiopia. J Int Acad Res Multidiscip. 2015;3(5):49-53.

15. Shittu RO, Sanni MA, Odeigah LO, Akanbi AA, Sule AG, Isiaka-Lawal S, et al. Awareness, knowledge and misconceptions about Ebola virus disease (EVD) in a family practice setting in Nigeria, West Africa. J Antivir Antiretrovir. 2015;7:10-4.

Cite this article as: Umamageswari A, Arumugam B, Nandini R, Nasrunisha I. Assessment of knowledge regarding prevention and treatment of Ebola virus among undergraduate medical students in Chennai, India: a questionnaire based study. Int J Basic Clin Pharmacol 2015;4:1024-8. 